\title{
Electromyography Evaluations of the masticator muscles during the maximum bite force
}

\author{
Electromyography evaluations of the masticator muscles during the maximum bite force
}

La electromiografía (EMG) se fundamenta en el registro del potencial de acción muscular o potencial de unidad motora, que es la sumación de los cambios eléctricos producidos por la contracción de todas las fibras musculares que componen la unidad motora. Aporta información del funcionamiento integral de todo el sistema motor: motoneurona superior e inferior, unión neuromuscular y músculo. Este potencial de unidad motora se obtiene con una contracción voluntaria leve del músculo registrado con un electrodo de aguja concéntrico insertado en el músculo que se está estudiando.

Este tipo de EMG proporciona registros de gran calidad y especificidad que permiten el estudio de las características de los potenciales de unidad motora para identificar diferentes enfermedades neurológicas que pueden afectar a cualquier componente de la unidad motora (motoneurona alfa del asta anterior medular, su axón y todas las fibras musculares inervadas por este axón y que, por tanto, van a ser activadas casi simultáneamente), la unión neuromuscular y el músculo.

La EMG de superficie se realiza con electrodos de superficie generalmente autoadhesivos que se colocan encima de la piel que recubre a los músculos, exploran mayor área del músculo, son inespecíficos, pero sirven para valorar los cambios de la actividad eléctrica muscular global durante el reposo y la contracción muscular máxima, siendo el resultado de las variaciones de voltaje que se producen en las fibras musculares, como expresión de la despolarización de las membranas celulares, durante la contracción; evalúan básicamente el patrón de contracción y cambios de amplitud. ${ }^{1}$

Los cambios de amplitud analizados automáticamente en el registro del EMG durante el máximo esfuerzo empleados con más frecuencia son: la amplitud pico a pico (amplitud P-P o P-P amplitude), que es la relación de la amplitud máxima del trazado respecto a la amplitud mínima a lo largo de todo el registro; la raíz cuadrada media del voltaje (Voltaje RCM, Voltaje RMS o RMS) calculada en el trazado EMG registrado; el voltaje medio rectificado (VMR, MRV), que es la amplitud media después de la rectificación de las ondas y se calcula en todo el trazado EMG y el número de vueltas por segundo (turns/s), que representa el número de "picos" (amplitud máxima positiva-negativa) en las ondas del trazado superior a 100 microvoltios durante un segundo del registro, suele ser un valor numérico normalizado.

Este tipo de registro permite también la valoración de los movimientos resultantes de la propia acción muscular. Con la EMG se puede observar y registrar perturbaciones funcionales no reconocibles por la observación clínica. ${ }^{2}$
Electromyography (EMG) is based on recording the muscular action potential or the potential of the motor unit, which is the sum of the electrical changes produced by the contraction of all the muscular fibers that compose the motor unit. It provides information on the comprehensive function of the entire motor system: upper and lower motor neuron, neuromuscular junction, and muscle. The action potential of the motor unit is obtained with a mild voluntary contraction of the muscle recorded with a concentric needle electrode inserted in the muscle under study.

This type of EMG produces recordings of high quality and specificity that allow the study of the characteristics of the motor unit potentials to identify different neurologic diseases that can affect any component of the motor unit (alpha motor neuron of the spinal anterior horn, its axon, and all the muscle fibers innervated by this axon that are activated almost simultaneously), neuromuscular junction, and muscle.

Surface EMG is performed with surface electrodes, generally self-adhesive, that are positioned on the skin covering the muscles. They explore a large area of muscle and are nonspecific, but they serve to assess the changes in the global electrical muscular activity at rest and maximum muscular contraction, being the result of voltage variations that occur in muscular fibers as the expression of cell membrane depolarization during contraction. Basically they evaluate the pattern of contraction and changes in amplitude. ${ }^{1}$

The changes in amplitude most often studied, which are automatically analyzed in the EMG recording during maximum effort, are: peak-to-peak (amplitude P-P or P-P amplitude), which is the relation between the maximum amplitude and the minimum amplitude throughout the entire recording; the mean square root of voltage (RCM Voltage, RMS Voltage, or RMS), calculated on the EMG tracing; mean rectified voltage (MRV), which is the mean amplitude after wave rectification and is calculated for the entire EMG tracing, and the number of turns per second (turns/s), which represents the number of "peaks" (maximum positive-negative amplitude) in the waves of the tracing above 100 microvolts during one second of recording. It usually is a standardized numerical value.

This type of recording also allows the evaluation of the movements resulting from muscular action per se. The EMG can be used to observe and record functional disturbances not recognizable by clinical observation. ${ }^{2}$ 
El músculo normal durante el reposo es eléctricamente silencioso y se va activando de manera progresiva en relación con la contracción muscular voluntaria.

La evaluación electromiográfica ha sido utilizada por diferentes autores en los últimos años no solo para el conocimiento de la mecánica mandibular:3-6 estudios centrados en la actividad de reposo, actividad en el esfuerzo máximo, balance muscular y simetría muscular sino también para el conocimiento de las alteraciones que producen numerosos síndromes craneomandibulares de origen muscular:7,8 hiperactividad o hipoactividad muscular, actividad muscular refleja o actividad parafuncional. Sería interesante una estandarización tanto de los protocolos de exploración como de los valores de normalidad para poder comparar los resultados obtenidos por distintos autores.

En la masticación, ${ }^{3,4}$ intervienen numerosos músculos: temporal, masetero, pterigoideo, digástrico, milohioideo y geniohioideo, sin embargo los músculos que se han estudiado mayoritariamente en estos estudios EMG han sido los músculos temporales y maseteros, ${ }^{9}$ por ser mas accesibles, de mayor tamaño y fácilmente localizables. ${ }^{10}$

Para la localización del músculo temporal el electrodo se coloca dos centímetros por encima del arco cigomático y dos centímetros posteriores a la comisura del ojo y para la del músculo masetero el electrodo se coloca un centímetro inferior al ángulo de la mandíbula, aunque el músculo masetero se delimita fácilmente mediante la palpación de la contracción muscular producida al apretar los dientes. Los dos músculos están inervados por ramas nerviosas procedentes del tronco anterior del nervio mandibular procedentes de la tercera división del nervio trigémino (rama motora).

Los autores efectúan un estudio prospectivo en 17 sujetos adultos sanos de la biomecánica mandibular mediante análisis electromiográfico de los músculos maseteros y de la región anterior del músculo temporal de ambos lados, izquierdos y derechos, durante el máximo esfuerzo de la mordida.

Realizan estudios poligráficos simultáneos de los músculos mencionados mediante EMG de superficie valorando variaciones de amplitud y el patrón de activación muscular durante el máximo esfuerzo de la mordida determinado por un transductor de presión insertado en un tubo de goma, cuyo sensor se conecta al sistema de registro EMG. El tubo de goma se coloca entre los molares superiores e inferiores en ambos lados. El esfuerzo se ejecuta tres veces consecutivas, con un entrenamiento previo, con una duración de 5 segundos e intervalos de 1 minuto.

La colocación del transductor de presión supone un aspecto interesante y novedoso por la reproductibilidad del máximo esfuerzo y la homogeneización de la fuerza entre los distintos sujetos.

El presente trabajo analiza la variabilidad de la actividad muscular demostrando una mayor participación de los músculos maseteros en la mordida máxima, siendo la activación muscular mayor que en los músculos temporales, estos resultados coinciden con los obtenidos por otros autores ${ }^{3,5}$ en estudios previos. Esta asimetría es menor en reposo que en la apertura máxima.

Como señalan los autores de este trabajo existe cierta asimetría en la activación muscular de los músculos maseteros con predominio en la activación del músculo derecho probablemente rela-
The normal muscle at rest is electrically silent and is activated progressively in relation to the voluntary muscular contraction.

Electromyographic studies have been used by different authors in recent years, not only to obtain knowledge of mandibular mechanics:-36 studies centered on activity at rest, activity during maximum effort, muscular balance and muscular symmetry. EMG has also been used to obtain knowledge of the alterations produced by that numerous craniomandibular syndromes of muscular origin:7,8 muscular hyperactivity or hypoactivity, reflex muscular activity, or parafunctional activity. Standardization of the examination protocols and values of normality would be useful for purposes of comparing the results obtained by different authors.

Numerous muscles participate in mastication:3,4 temporal, masseter, pterygoid, digastric, myohyoid, and geniohyoid. However, the muscles that have been studied in these EMG studies have been mainly the temporal and masseter, ${ }^{9}$ because they are more accessible, larger, and easily located. ${ }^{10}$

The temporal muscle is located by placing the electrode two centimeters above the zygomatic arc and two centimeters posterior to the eye commissure. For the masseter muscle, the electrode is placed one centimeter below the jaw angle, although the masseter muscle is delimited easily by palpation of the muscular contraction produced when gritting the teeth. The two muscles are innervated by branches of the anterior trunk of the mandibular nerve issued by the third division of the trigeminal nerve (motor branch).

The authors made a prospective study in 17 healthy adult subjects of mandibular biomechanics by electromyographic analysis of the masseter muscles and the anterior region of the temporal muscle on both sides, left and right, during maximum bite effort.

Simultaneous polygraphic studies were made of the masseter and temporal muscles by surface EMG. Amplitude variations and the pattern of muscular activation were evaluated during the maximum bite effort, determined by means of a pressure transducer inserted in a rubber tube, with the sensor connected to the EMG recording system. The rubber tube is placed between the upper and lower molars on both sides. This effort is repeated three times consecutively, after a warm-up period, for a duration of 5 seconds and at 1-minute intervals.

The placement of the pressure transducer is an interesting and novel aspect due to the reproducibility of the maximum effort and the homogenization of force between different subjects.

The present study analyzes the variability of the muscular activity, demonstrating greater participation of the masseter muscles during the maximum bite and more muscular activation than in the temporal muscles. These results coincide with those obtained by other authors ${ }^{3-5}$ in previous studies. This asymmetry is smaller at rest than during maximum opening. 
cionado con la dominancia hemisférica y que debe ser considerado como normal, como ya han señalado otros autores previamente. ${ }^{11}$

En este estudio se evidencia una mayor fuerza en los músculos maseteros de los hombres relacionada por los autores con el tamaño muscular, aunque esta asimetría en relación al sexo no es objetivada en otros trabajos previos. ${ }^{6}$

Parece por lo tanto y apoyando las conclusiones de los autores, como las de otros autores previamente,,$^{5,7-9}$ que la actividad eléctrica muscular registrada mediante EMG de superficie aporta una guía funcional útil y reproducible de la mecánica mandibular en sujetos sanos y puede ayudar a entender las variaciones del comportamiento muscular de estos músculos en pacientes portadores de prótesis, 8 con maloclusiones, síndromes craneomandibulares o enfermedades musculares.

\section{Mercedes González Hidalgo} Sección de Neuromuscular. Servicio de Neurofisiología Clínica. Instituto de Neurociencias. Hospital Clínico Universitario San Carlos. Madrid. España
As the authors of the study indicate, there is a certain asymmetry in the muscular activation of the masseter muscles, with predominance in the activation of the right muscle. This probably is related with hemispheric dominance and should be considered as normal, as has been pointed out by other authors. ${ }^{11}$

This study evidenced more force in the masseter muscles of men, which the authors attributed to muscle size, although this gender-related asymmetry has not been observed in previous studies. ${ }^{6}$

Therefore, in confirmation of the conclusions of the authors and others, 5,7-9 it seems that the muscular electrical activity recorded by surface EMG provides a useful and reproducible functional guide to mandibular mechanics in healthy subjects. EMG can assist in understanding variations in muscular behavior 8 in patients with prostheses, malocclusion, craniomandibular syndromes or muscular diseases.

\section{Bibliografía}

1. Mejuto FJ, Villalibre I, González Hidalgo M, Franco C. Quantitative evaluation of the maximal voluntary activity pattern. EEG and Clinical Neurophysiology 1998; 106:29.

2. González-Hidalgo M, Saldaña Galán C], Franco Carcedo C, Mata González P. The usefulness of electromyographical monitoring with intraoperative brain mapping during lesionectomy. Clinical Neurophysiology 2002;113(suppl1):623.

3. Vitti M, Basmajian JV. Integrated actions of masticaty muscles: simultaneous EMG from eight intramuscular electrodes. Anat Rec 1977;187:173-89.

4. Wood WW. A review of masticatory muscle function. J Prosthet Dent 1987; 57: 222-32.

5. Visser A, McCarroll RS, Naeije M. Masticatory muscle activity in different jaw relations during submaximal clenching efforts. J Dent Res 1992;71:372-9.

6. Ferrario VF, Tartaglia GM, Galeta A, Gras GP, Sforza C. The influence of occlusion on jaw neck muscle activity: a surface EMG study. J Oral Rehabil 2006; 33:341-8.

7. Bosman F, van der Glas HW. Electromyography aid in diagnosis, theraphy and theraphy evaluation in temporomandibular dysfunction. Ned Tijdschr Tandheelkd 1996;103:254-7.

8. Zuccolotto MC, Vitti M, Nóbilo KA, Regalo SC, Siéssere S, Bataglion C. Electromyographic evaluation of masseter and anterior temporalis muscles in rest position of edentulous patients with temporomandibular disorders, before and after using complete dentures with sliding plates. Geodontology 2007;24:10510.

9. Rodríguez KA, Ferreira LP. Masseter muscles electromyography study of individuals with and without malocclusion during dental clenching. Electromyogr Clin Neurophysiol 2004;44:271-5.

10. Perotto AO. Anatomical guide for the electromyographer. Charles $C$ Thomas Publisher. Third edition. Sprinfield. Illinois. USA, 1994;p:253-6.

11. Ferrario VF, Sforza C, Colombo A, Ciusa V. An electromyographic investigation of masticatory muscles asymmetry in Normo-occlusion subjects. J Oral Rehabil 2000; 27:33-40. 